\title{
Advancing Students' Environmental Sustainability Awareness Through Science Mobile Learning: A Literature Review
}

\author{
Aza Ayu Din Illahaqi ${ }^{1, *}$ Heru Nurcahyo ${ }^{2,}$ Muchtar Haryanto Panjaitan ${ }^{1,}$ \\ ${ }^{1}$ Master of Natural Natural Science Education, Faculty of Mathematics and Natural Sciences, Universitas Negeri \\ Yogyakarta, Indonesia \\ ${ }^{2}$ Department of Natural Science Education, Faculty of Mathematics and Natural Sciences, Universitas Negeri \\ Yogyakarta, Indonesia \\ *Corresponding author.Email: azaayu.2019@student.uny.ac.id
}

\begin{abstract}
Environmental Sustainability Awareness (ESA) should be built since early because it is a very important component to support Sustainable Development (SD). Educators have been made various attempts to improve student's ESA such as using different learning models, methods, and media or teaching materials in the learning process. However, some studies reveals that students had a good awareness of environmental problems but had not changed in practice. Learning independent of time and space concept has gained importance. Mobile learning (m-learning) can be used as an alternative learning resources to advance ESA. This literature study aims to give overview how to advance ESA through science m-learning. There are 5 content in m-learning science that will help students to advance their awareness on environmental sustainability: scientific content (i.e global warming, climate change, air polution, water polution, biodiversity), instant notification, social network support, and gamification. The authors suggest that it is essential to design science m-learning and the material can be taught both inside and outside the classroom.
\end{abstract}

Keywords: Environmental sustainability awareness, Mobile learning, Science education

\section{INTRODUCTION}

The inhabitants of the earth currently have been faced with world's environmental crisis, such as global warming, water and air pollution, depletion of the ozone layer, and tropical rain forests that resulting in crisis biodiversity. All these problems make people no longer able to survive both within the scope of local or global. It was not just the responsibility of adults, but future generations are most important that will face the sustainability issues.

Sustainability embraces various perspectives including economic, social, cultural, and environmental issues in pursuit of economic development, human welfare, and ecosystem integrity [1]. Environmental sustainability awareness (ESA) is one of critical element of Sustainable Development (SD) that focuses on environmental dimension. ESA is part of prerequisite for a change in attitude and behavior environment in treating the natural environment to hinder climate change and global warming [2]. It should be built since early because it is a very important component to support sustainable development [3]. The impact of climate change is the phenomenon that is common. Students should early faced with the danger of climate change for help them develop positiveness concerning the environment and lessen the risk related to it by means of living a sustainable lifestyle [4].

Education is the bridge to sustainability. Students perhaps having less consciousness because they do not completely understand what is happening in their environment or how dangerous the effects of global warming are to the environment. Students must have reasoning in science, so that they can relate concepts to the daily phenomena. Therefore, this is a challenge for teachers to build or increase student awareness of environmental sustainability [5]. 
Some studies have shown that secondary school students had a good awareness of environmental problems but had not changed in practice [6], [7], [8], [9]. The practice of sustainability awareness aspect is the lowest percentage among other aspects. This aspect is very difficult to achieve. Students should have awareness in discussing or conveying information about environmental problems and taking action to protect the environment. Students might get environmental and awareness lesson from home and school.

The development of technology in education has been growing rapidly. It can be used in learning, such as learning media that used to convey learning material to students. The development of technology information can also be used educators to create learning more attractive, varied, and also improve learning.

Nowadays, smartphone has become an essential part of the lives of young people because it easy to obtained and to operate. Now, it is a lot of smartphone that generally based android to circulate in the community especially among students. An android smartphone has plenty of facilities such as laptop/pc that could support learning activities. Hence, many educators have attempted to take advantage of this device enhance student learning experiences, created a new trend in education called mobile learning (mlearning).

A study was conducted to see the potential of mlearning in environmental education for sustainable development [10]. The results of the study stated that $\mathrm{m}$-learning has potential because of its benefits such as the chance to be used in conjunction with classroom activities, to be able to use in outside the classroom, and helps students to analyze their own content.
The remainder of this paper is structured as follows: section 2 provides an overview of science $m$ learning advance environmental sustainability awareness. Section 3 concludes this work.

\section{A REVIEW OF ADVANCING ESA THROUGH SCIENCE MOBILE LEARNING}

This section provides an overview of advancing ESA through science mobile learning.

\subsection{Environmental Sustainability Awareness}

ESA is one of the prerequisites for environmental attitude and behavioral change in caring for the natural environment in the face of impeding climate change and global warming [2]. Globe Scan has been holding multi-country annual polls on environmental issues since 1992. To that end, citizens from 12 countries have asked whatever they consider each of the six environmental problems: air pollution, water pollution, species, car emissions, shortages of fresh water, and climate change [11].

Based on a review of several articles, the main aspects that form the basis of ESA [6],[8], [9], [12], namely (1) emotional, (2) attitude, and (3) practices of sustainability awareness as set out in Table 1 . In conclude, ESA is a student competency to explain, experiment, and interpret data scientifically so that it can solve problems or issues in a personal, local, national and global context. This competence can be achieved by students if they have good attitudes and knowledge in the field of science.

Table 1. Indicators of ESA

\begin{tabular}{|l|l|l|}
\hline \multicolumn{1}{|c|}{ No } & Aspect & \multicolumn{1}{|c|}{ Explanation } \\
\hline 1 & Sustainability practice awareness & $\begin{array}{l}\text { Aspect that show students activity do practices that relate to } \\
\text { environmental component in their daily lives in a sustainable way and } \\
\text { continuously. }\end{array}$ \\
\hline 3 & Behavioral and attude awareness & $\begin{array}{l}\text { Aspect that show awareness students for applying an act of pertaining to } \\
\text { environmental problems or an attitude and habits that they do daily } \\
\text { pertaining to the environment as read environmental issues, appreciate } \\
\text { good activities for the environment, recycling, and others. }\end{array}$ \\
\hline 3 & Emotional awareness 1 & $\begin{array}{l}\text { Aspect that show awareness emotionally from students about their } \\
\text { responsibilities for environmental problems around them, for example as } \\
\text { expression disappointment school tuition to pollution occur in the } \\
\text { neighborhood. }\end{array}$ \\
\hline
\end{tabular}




\subsection{Science M-Learning}

M-learning simply can defined as an application device cellular, as a smartphone, laptop, computer, and the reader electronic, to allow learning electronics (elearning), allows school tuition to learn anytime and anywhere, then confining them to limits classrooms [13]. Rapid growth cellular technology has characteristics that are expected to become the learning revolution. Studies show that with the use of cellular communication technology for the purpose of learning in this case m-learning, having excess as improving communication and collaboration, support in the project, group work and filling students time in the environment are physically different with activities pertaining to learning [14]. M-learning refers to the use of mobile devices digital portable and can be used to facilitate and promote learning [15]. In addition, with matter m-learning, the students had a chance to get the benefits for learning environment of a lifetime and did not realize, studying at the time it takes, learned self-conscious of time and place, so that the process easier [16].

Learning by applying m-learning having some function. M-learning has three functions in learning activities classroom instruction, that is as supplement which are optional, complement, or substitution. Mlearning solve limited to material or allocation of time and training to student independent study from various sources provided [17]. There are several factors to motivate students to use mobile application. Factors that influence classified into three major categories which are the features of the device that contain uses and functional, user's expectations that contain about ownership, personal, self-regulated, flexible learning, pleasing, and the last are profit pedagogies [18]. Students' perceptions and needs about the m-learning environment must be determined [19]. Thus, an efficient learning environment must be designed according to the perceptions and needs of students [20].

\subsection{Advancing ESA Through Science Mobile Learning}

M-learning will add effectiveness that motivates participatory method of learning and empowering students to change their habits, and take action on the environment and sustainable development [21]. The basic purpose of the mobile application has been developed for college students. Education for the purpose of sustainable development is the use of applications and their benefits for students. Several studies can be said in line with research conducted by
[22] because observed in support in this study that technology cellular impact on student during for the purpose of education. sustainable development. Hence, it is recommended to use application cellular learning support traditional teaching methods in education for the purpose of sustainable development. It is believed that the mobile learning must be developed in such a way so allowing activity in the classroom and outside the classroom. Students can make and to share their own content and at the end of the application, it affects the level of consciousness students [10]. The majority of students are satisfied to connect with friends and their teachers for learning, maybe it was recommended that adding any new portion of sports as a message, a letter or social network on the application m-learning developed.

Application m-learning developed must have scientific and social content, instant notice, gamification based and the user relating to the ESA. Content m-learning includes teaching matter open source education and enriched with notification, communication, support social network, gamification cellular and content of technology. M-learning will fill the object and meet student needs well. Research stated that students become contented to follow the rescue activities plant trees or gardening when be home; hence this indicates that not be too difficult to increase awareness of sustainable development by means of technology and engineering proper education training. Remarkable conclusion from the findings of this study are students like to conduct which would benefit the community, such as planting trees or share information about sustainable development with the help of mobile social networking on the application. The study also stated that social network of application and the cellular gamification effective to accelerate interaction with other students, and the enables the student for delivering mail to educator effective to accelerate interaction with educator. Educators can integrate activities to support student practice by using $\mathrm{m}$ learning.

The themes curricular indicative that may be more or less relevant to each discipline sector and probably used and adapted as entry points to develop environmental sustainability further [23]. There are management of natural resource, food and agriculture, ecological system, waste/water/energy, biodiversity, and climate change. Thus, the content that needed in a science m-learning to improve indicators environment sustainability awareness contains: (1) scientific content (i.e climate change, resource waste, biodiversity, air/water/soil polution, and energy); (2) instant notification; (3) social network support, and (4) 
gamification. A very strong correlation has been found between m-learning design and academic performance. So, the material to be taught in outside classrooms and procedures must be known and flexible for the user [24]. Some research suggested that the tools of m-learning can work without an internet connection. can be used at all levels of teaching and can have different language options [25].

Table 2. Sustainability competences

\begin{tabular}{|c|c|c|}
\hline No & Competency & \\
\hline 1 & $\begin{array}{lr}\text { System thinking and } \\
\text { understanding } \\
\text { interconnectedness }\end{array}$ & $\begin{array}{l}\text { The world is becoming increasingly interconnected. As a result of the decisions } \\
\text { made in one region, influence other regions in complex array of local to global } \\
\text { interactions of human-environment and impacts. In applying systems thinking in } \\
\text { an educational context, it is important not only to talk about interconnected global } \\
\text { systems but also for the interconnectedness of systems at the household, } \\
\text { classroom and school scales, these are systems that impact and interact with } \\
\text { students on a regular basis. Understanding patterns and interactions enables us } \\
\text { to transform system processes and components more effectively. }\end{array}$ \\
\hline 2 & $\begin{array}{lr}\text { Longterm, } & \text { foresighted } \\
\text { reasoning, } & \text { and } \\
\text { strategizing } & \end{array}$ & $\begin{array}{l}\text { Foresighted thinking entails an understanding that the actions we take today have } \\
\text { consequences long in the future. A general vision for the sustainable includes four } \\
\text { key steps: (1) describe the current circumstances; (2) understand possible future } \\
\text { scenarios (based on he trend in the past, present, and future); (3) vision statement, } \\
\text { imagine an ideal future state; (4) Action plan, develop strategies to move from the } \\
\text { current state to the envisioned state. }\end{array}$ \\
\hline 3 & $\begin{array}{l}\text { Stakeholder } \\
\text { engagement and } \\
\text { group collaboration }\end{array}$ & $\begin{array}{l}\text { Collaboration is needed in Sustainability to take into account diverse values and } \\
\text { normative perspectives on how they should be. By involving stakeholders can build } \\
\text { competencies including providing skills and resources for students to take roles. } \\
\text { Such as collaborative decision-making, conflict mediates conflicts between } \\
\text { opposing perspectives, and negotiates various stakeholder interests while looking } \\
\text { at different visions of the present, past, and future. The classroom atmosphere } \\
\text { should foster collaboration and community interaction and help interpersonal } \\
\text { skills develop open discussions that allow multiple perspectives to be heard and } \\
\text { acted on. }\end{array}$ \\
\hline 4 & $\begin{array}{l}\text { Action orientation and } \\
\text { change-agent skills }\end{array}$ & $\begin{array}{l}\text { Sustainability is a call to action. It is very important to educate students in shaping } \\
\text { their future for sustainability, students are equipped with the skills and confidence } \\
\text { to take action and become active participants. Progress towards sustainability } \\
\text { requires educating teachers and students for sustainability, not only about } \\
\text { sustainability and in doing so they must move beyond an information-based } \\
\text { approach and include action as a core competency. The examples of action- } \\
\text { oriented education are students reducing single-use plastics, bringing their own } \\
\text { bottles, make compost, recycle, and so on. }\end{array}$ \\
\hline
\end{tabular}

The science m-learning is also should be integrate with sustainability competences approach. Competency refers to concepts and skills that enable students to understand and solve complex problems and tasks of sustainability [26]. Sustainability competencies include (1) systems of thought and understanding of linkages, (2) long term and farsighted reasoning, and strategy development, (3) stakeholder and group collaboration, and (4) action orientation skills and change agents [27], as set out in Table 2.

In addition, there are additional areas called for possible future research in the mobile learning of science. For example, most of the studies in this 
review focused on undergraduate students. What's more, only a handful of studies in this review focused on junior secondary students. Thus, there is necessity for future research to examine how m-learning can be used with a more diverse population of students and how mobile learning can be used with a wider variety of topics. The majority of the studies in this review focus on the life sciences. Therefore, more research on cellular learning in the earth and physical sciences and multidisciplinary topics is needed. These recommendations pass from a recent review noted that mobile learning research in astronomy, physics, and chemistry is needed [28].

\section{CONCLUSION}

Science m-learning can be intergrated to advance student's ESA especially to support student practice. Through some literature reviews, environmental sustainability is connected with several topics on science learning in junior high school. This literature review involved 26 references consisting of several international and national articles and e-books. There are 5 content in m-learning science that will help students to advance their awareness of environmental sustainability: scientific content (i.e air pollution, water pollution, biodiversity, global warming, climate change), instant notification, social network support, and gamification. The content of science m-learning can help educator to increase students' attitude, motivation, and the depth of learning material. Science m-learning provides student learning experiences because students can learn on their own. Students have the opportunity to benefit from environmental and unconscious learning, learning when it is needed, learning unconsciously from time and place. So, it will empower students to change their habits. Moreover, further research needs to examine the effectiveness relationship between these factors and their change with the potential of technology to alter the learning experience on student.

\section{REFERENCES}

[1] UNESCO, Education for Sustainable Development Country Guidelines for Changing the Climate of Teacher Education to Address Sustainability: Putting Transformative Education into Practice, UNESCO Digital Library, 2011.

[2] S. Hamid, M.T. Ijab, H. Sulaiman, R. Md. Anwar, A.A. Norman, Social Media for Environmental Sustainability Awareness in Higher Education, International Journal of Sustainability in Higher Education 18(4) (2017) 474-491. DOI: https://doi.org/10.1108/IJSHE-01-2015-0010

[3] Nursadiah, N. Suyana, T. R. Ramalis, Profil sustainability awareness peserta didik melalui integrasi esd dalam pembelajaran berbasis masalah pada topik energi di SMP, in: Prosiding Seminar Nasional Fisika, vol. 4, UPI, Bandung, 2018, pp. 207-211.

[4] C. Njoku, Awareness of Climate Change and Sustainable Development Issues among Junior Secondary School (JSS) Students in Port Harcourt Metropolis, International Journal of Curriculum and Instruction 8(2) (2016) 29-40.

[5] D. Hodson, Teaching and Learning about Science: Language, Theories, Methods, History, Traditions and Values, Brill, 2009.

[6] A. Hassan, T.A. Noordin, S. Sulaiman, The status on the level of environmental awareness in the concept of sustainable development amongst secondary school students, in: Procedia Social and Behavioral Sciences, vol. 2, Elsevier, Amsterdam, 2010, pp. 1276-1280. DOI: https://doi.org/10.1016/j.sbspro.2010.03.187

[7] A. Hassan, N.A. Rahman, S I.S S. Abdullah, The level of environmental knowledge, awareness, attitudes and practices among UKM students, in: University Kebangsaan, vol. 13, UKM, Malaysia, 2011, pp. 5-8. DOI: https://doi.org/10.1016/j.foodcont.2013.09.036

[8] I.I. Pratiwi, A.F.C. Wijaya, T.R. Ramalis, Penerapan PBL dengan konteks ESD untuk meningkatkan hasil belajar kognitif peserta didik, in: Prosiding Seminar Nasional Fisika (EJournal), vol.8, UNJ, Jakarta, 2019, pp. -1-8. DOI:

https://doi.org/10.21009/03.SNF2019.01.PE.01

[9] E.R. Salsabila, A.F.C. Wijaya, N. Winarno, Improving Students' Sustainability Awareness through Argument-Driven Inquiry, Journal of Science Learning 2(2) (2019) 58-64. DOI: https://doi.org/10.17509/jsl.v2i2.13104

[10] S. Bleck, M. Bullinger, A. Lude, S. Schaal, Electronic mobile devices in environmental education (EE) and education for sustainable development (ESD)-Evaluation of concepts and potentials, in: Procedia Social Behavioral Sciences, vol. 46, Elsevier, Amsterdam, 2012, pp. 1232-1236.

DOI: https://doi.org/10.1016/j.sbspro.2012.05.280 
[11] E. Kokkinen, Measuring Environmental Awareness in The World, University of Oulu, 2013.

[12] A. Amran, M. Perkasa, M. Satriawan, I. Jasin, M. Irwansyah, Assessing students 21st century attitude and environmental awareness: promoting education for sustainable development through science education, in: Journal of Physics: Conference Series, vol. 1157, IOP Publishing, Bristol, 2019, pp. 1157-1167. DOI: https://doi.org/10.1088/17426596/1157/2/02202 5

[13] Y.M. Huang, P.S. Chiu, The Effectiveness of A Meaningful Learning-Based Evaluation Model for Context-Aware Mobile Learning, British Journal of Educational Technology 46(2) (2015) 437-447. DOI: https://doi:10.1111/bjet.12147

[14] G. Gay, M. Stefanone, M. Grace-Martin, H. Hembrooke, The Effects of Wireless Computing in Collaborative Learning Environments, International Journal of HumanComputer Interaction 13(2) (2001) 257-276. DOI:

https://doi.org/10.1207/S15327590IJHC1302_10

[15] M. O'Connell, J. Smith, A Guide to Working with Mlearning Standards: A Manual for Teachers Trainers and Developers, Australian Flexible Learning Network, 2007.

[16] M. Bulun, B. Gülnar, S. Güran, Egitimde Mobil Teknolojiler, The Turkish Online Journal of Educational Technology 3(2) (2004) 165-169.

[17] R.B. Purnama, F. Sesunan, C. Ertikanto, Pengembangan Media Pembelajaran Mobile Learning Berbasis Android sebagai Suplemen Pembelajaran Fisika SMA pada Materi Usaha dan Energi, Jurnal Pembelajaran Fisika 5(4) (2017) 63-74.

[18] S. Bidin, A.A. Ziden, Adoption and application of mobile learning in the education industry, in: Procedia-Social and Behavioral Sciences, vol. 90, Elsevier, Amsterdam, 2013, pp. 720-729. DOI:

https://doi.org/10.1016/j.sbspro.2013.07.145

[19] N. Menzi, Ö. Nezih, E. Çalı,skan, Investigating Educational Researchers' Views of Using Mobile Technologies for Educational Purposes Based on Technology Acceptance Model, Ege Journal Education 13(1) (2012) 40-55.
[20] M. Elçiçek, F. Bahçeci, The Research of the Vocational School Student's Attitudes towards Mobile Learning, The Journal of Education Faculty Sakarya University 30(1) (2015) 17-33.

[21] S. Shah, V.V. Ramanan, Environmental Education and Education for Sustainable Development through Mobile Learning: Transgressing The Geographical Boundaries, Open and Distance Learning Initiatives for Sustainable Development, (2021) 1135-1157. DOI: https://doi.org/10.4018/978-1-5225-26216.ch005

[22] R.N. Madeira, V. Pires, O.P. Dias, J. Martins, An Analog Electronics Mobile Course with A Competitive Learning Approach, International Journal Interactive Mobile Technologies 4(4) (2010) 37-44. DOI: https://doi.org/10.3991/ijim.v4i4.1415

[23] D. Tilbury, D. Wortman, Engaging People in Sustainability Commission on Education and Communication, IUCN, 2004.

[24] S.F.A. Hossain, X. Shan, M. Nurunnabi, Is MLearning a Challenge?: Students Attitudes toward the Sustainable Learning and Performance, International Journal of eCollaboration 15(1) (2019) 21-37. DOI: https://doi.org/10.4018/IJeC.2019010102

[25] B. Turan Çimşir, H. Uzunboylu, Awareness Training for Sustainable Development: Development, Implementation and Evaluation of a Mobile Application, Sustainability 11(3) (2019) 611-628. DOI: https://doi.org/10.3390/su11030611

[26] E. Frisk, K.L. Larson, Educating for Sustainability: Competencies \& Practices for Transformative Action, Journal of Sustainability Education 2(1) (2011) 1-20.

[27] E. Redman, Advancing Educational Pedagogy for Sustainability: Developing and Implementing Programs to Transform Behaviors, International Journal of Environmental and Science Education 8(1) (2013) 1-34.

[28] G.J. Hwang, P.H. Wu, Applications, Impacts and Trends of Mobile Technology-Enhanced Learning: A Review of 2008-2012 Publications in Selected SSCI Journals, International Journal of Mobile Learning and Organisation 8(2) (2014) 83-95. 